会話中に「相手を知っている」と言うことの会話分析的研究

〜付き合う男女のインターネットチャットを題材に〜

大阪大学大学院 言語文化研究科 日本語 - 日本文化専攻 博士前期課程

千々岩 宏晃

\title{
SAYING I KNOW YOU \\ - CONVERSATIONAL ANALYSIS \\ ON INTERNET-CHATTING BY DATING COUPLES -
}

Hiroaki Chijiiwa

\begin{abstract}
Assosiate of Research Department Japanese
and Japanese Culture Department for Master and Doctor Degree, Osaka University

chiji.hiro@gmail.com
\end{abstract}

\begin{abstract}
概要
中山（2003） は、普段人々は「私たちの親しさはこのぐらい」というような言語形式によって、 お互いに親しさを確かめ合うことを行わない、と述べている1。確かに、親しさ」と呼ばれる非常に曖 昧な概念において、その尺度を演繹的に決定することは非常に困難であり、ましてや、対話の中でそ のようなことを行うことは難しいであろう。しかし、人々は尺度的に行うことはないまでも、会話中 で二者間の関係に言及し、二者間の関係が発展したことを確認しあうことは「まったく」行わないの であろうか。本研究は、以上の疑問を解消するために、付き合う男女のインターネットチャットのデ 一タを会話分析の手法に基づいて分析し、付き合う男女二者間で起こった言語活動による二者間の関 係の「親しさのストラテジー」としての「相手を知っている」発話の機能を帰納的に抽出しようとす る質的研究である。心理学的見地での「透明性の錯覚」についての研究は、主に相手に自分の思考が ばれていると認知する傾向の言説であった。しかし、ここで行われていることは、発話者が被発話者 に対して「知っている」と述べる行為であり、被発話者は「知られている」と示される、という活動 であった。

キーワード : 親しさ・親密度，会話分析，インターネットチャット，透明性の錯覚
\end{abstract}

\begin{abstract}
In casual conversations, Japanese people do not refer to their intimacies saying "We are close this much." It is difficult to create special scales for intimacies because the term of "Intimacy" is too abstract and vague. However, don't Japanese people really scale their intimacies during their conversations? In this study, the researcher aimed to describe strategies of intimacies in Japanese using method of Conversational Analysis onto dating couple's casual internet chat data and analyzed "how people show their intimacies to opponent through the conversations." For conclusion we can say; Japanese people tend to say "I know you" in indirect way to emphasize the opponent's "the illusion of transparency".
\end{abstract}

Keywords: Intimacies, Closeness, Conversational Analysis, Internet Chatting, Illusion of transparency

\footnotetext{
とはいっても、会話で「出会ったときはこんなに仲良くなるとは思わなかった」と述べることはたびたびあるように思われる が、これについては別に考える必要があるであろう。

こここでの「機能」とは、「発話機能」のことではなく、それをつかって会話参与者が何をしているかを表す。
} 


\section{研究目的}

中山（2003）は、普段人々は「私たちの親しさはこのぐらい」というような言語形式に よって、お互いに親しさを確かめ合うことを行わない、と述べている3。

確かに、親しさ」と呼ばれる非常に曖昧な概念において、その尺度を演繹的に決定すること は非常に困難であり、ましてや、対話の中でそのようなことを行うことは難しいであろう。 しかし、人々は尺度的に行うことはないまでも、会話中で二者間の関係に言及し、二者間の 関係が発展したことを確認しあうことは「まったく」行わないのであろうか。

二者間の関係の変化によって、つまり二者の関係の発展（つまり、恋愛結婚や婚約、付 き合い始めることなど）や、社会的（あるいは法的）な約束によって生まれた関係の変化を 準物理的な関係の変化の証と捉えて、関係が発展したと述べることは、比較的容易ではある 。しかし、それら関係の変化「以降」、つまり、社会的拘束による関係の変化が顕著に見ら れない二者関係はどのように二者間の関係の発展を同定し、それを二者間で認めているのだ ろうか。

本研究は、以上の疑問を解消するために、付き合う男女のインターネットチャットのデ ータを会話分析の手法に基づいて分析し、付き合う男女二者間で起こった言語活動による二 者間の関係の「親しさのストラテジー」としての「相手を知っている」発話の機能

孛帰納的に抽出しようとする質的研究である。

\section{先行研究}

本節では、本研究の基礎となる「親しさ」ならびに「親密度」に関するいくつかの研究 、言説を概観し、その研究における問題点と本研究への応用を検討寸る。なお、以下本研究 で述べる「親しさ」とは、大坊（2004）の述べる親密度に関する分類の中の「認知的親密感 」ならびに、親しさを保つための「対人コミュニケーション行動の連鎖（親密な行動）」に 当てはまるが、以下で述べるように帰納的研究のため、具体的定義はここでは行わない。

\section{対人関係の社会学的言説分析の問題 : 加藤 (2008)}

加藤（2008）は、親密性に関する言説を分析することについての問題点を考察した。加 藤によれば、「親密性に関する言説の多くの概念が研究者によって操作的に定義されていた り、あるいは明確な定義のないまま日常語としての意味内容が暗黙のうちに想定されていた りする」ことが問題であり、研究対象を曖昧にするものであると述べている。

また、「客観的」概念を用いようとした社会学や心理学における量的研究（例えば、質 問紙等による回答）には、回答者がその概念の「イデオロギー（または、「あるべき姿」） 」を答えてしまう傾向がある

5とアラン（1993）を引用して述べ、「現実のあり方」と「イデオロギー」を分析的に区別

とはいっても、会話で「出会ったときはこんなに仲良くなるとは思わなかった」と述べることはたびたびあるように思われる が、これについては別に考える必要があるであろう。

4 ここでの「機能」とは、「発話機能」のことではなく、それをつかって会話参与者が何をしているかを表す。

5 加藤 $(2008$

:p.16）には例えとして、「「親友と共にする行動」を「親友とともに卞るべき行動」としての問いと解釈される」ことが述べ られている。 
することが問題であると述べている。さらに、加藤は対人関係に関する言説の多様性につい て述べ、それを「どう定義するか」「何が要件になるのか」「何が起こっているのか」「ど うあるべきか」の四つにまとめている。

加藤の問題点の考察は、まさにこれから本稿で述べようとするものの必要性を指摘する ものである。千々岩（2011）では、久保（1993）、中山（2003）、高木（2009）、前澤（20 08）などの問題点として、加藤が言及した「操作的定義」を挙げ、その中で行われた「親し さ」の概念を先行的に（時に十分な根拠を示さないまま）決める「演繹的研究」による研究 成果に対して疑問を呈した。

確かに、加藤が「友人と特徵づける「外的な」根拠はない」とアランを引用して述べる ように「必ずしもこのレベルの問題は重要なものとは限らない」かもしれない。しかし、こ れまでの親しさに関する研究において、「親しさ」や「友人」という尺度を用いる場面では 、多くの場合この操作的定義があり、それゆえに曖昧とした結果になってしまったことは事 実である。また、そのことは留意され、避けられるべきものである。このことは、本研究を 行う動機でもあり、3.2で詳しく示すように、本研究では帰納的研究を主とする必要が出て くるのである。

\section{自他領域概念に基づく「笑い」の分類 : 早川（2000a，2000b）}

早川（2000a）は、自・他領域という点に着目し、会話における笑いについて研究した 。早川は、笑いを3つ（A類：仲間づくりの笑い、B類 : バランスの笑い、C類 : 覆い隠す笑い ）に大別し、さらにそれぞれを下位分類した。また、早川（2000b）では、それを数量的デ ータを用いて実証し、さらにA類は親しい関係間や、雑談場面、B類は「普通」の関係や、ミ ーティングの場面で多発することを述べた。

確かに、早川の研究は笑いを一括で処理する（=言語の音声的側面を考慮しない ）ことで、言語の一側面である笑いの相互行為側面を抽出することに成功している 。しかしながら、分析中に使われている「親しい」関係は2.1で述べたように先行的 に決定されているものであり、それぞれの言葉の定義があいまいであることも問題 視されるであろう。

とはいえ、1で触れ、後に3.1で述べるように、これから分析するデータには音声 的側面がないため、音声的側面を排した笑いの分析は、有用であろうと思われる。

\section{親密な関係におけるメタ認知バイアスについての研究 : 工藤（2007）}

工藤（2007）は、自分の考えが相手に分かると推測するメタ認知バイアス（＝「透明性 の錯覚」）を中心に据え、その傾向が親しい友人間で大きくなること、また、それが社会的 規範（ここでは加藤の述べる「あるべき姿」と同様の意味）と関係があるかを心理学的視点 から研究した。後者についてはその仮説が棄却されたと述べる一方、前者については肯定し 、さらに、その逆（つまり、相手の考えがわかると錯覚する傾向）も親密な友人間では高い 数值を示寸ことが示された。さらに、工藤は、研究の全体考察の中で、次のように述べてい る。 


$$
\text { インセンティブ6 }
$$

がない状態の推測も、考慮した結果生じた判断と考えられる。友人間においては、主観的に 正確な推測をした結果が大きな透明性の錯覚として表れていると考えられる。

\section{（（引用者 中略））}

インセンティブがない状態での判断がすでに熟慮したものである可能性も指摘できるが 、逆に透明性の錯覚が熟慮しても低減できないバイアスである可能性も示唆している。その ように特に親密な関係における透明性の錯覚が頑健なバイアスであるとすれば、その背後に は適応的、機能的意味がある可能性が考えられるだろう。

工藤（2007） pp. 74-75

ここで、工藤の述べる「透明性の錯覚の背後にある応用的、機能的意味」とは、まさに 本研究でこれから明らかにしようとすることと関係がある。インセンティブがない場合でも 、平時から透明性の錯覚について熟慮しているということは、親密な関係において「知られ ていること」による何かしらの「相互行為的価值」があることが示唆されているためだ。そ して、その相互行為は、まさにこの研究で使用する会話分析の分析対象として主流のもので ある（3.2参照）。

また、逆の傾向（相手の考えがわかると錯覚する傾向）についても、インセンティブが あれば、未知の間柄でも友人間と同程度の推測量が得られると述べていることも興味深い。 ただし、ここでいうインセンティブが、日常の文脈でどのような形で表れているのかは、さ らに考察をする必要があるように思われる。

\section{先行研究から得られたこと}

本節で概観したこれら三つの先行研究から、以下のようなことが導き出されるであろう

1. 親しさに関する分析は、その定義の操作性・曖昧性などから、帰納的研究が求められて いる。

2.「親しい」とすでに操作的に定義された研究の中でも、本分析への適用は十分に可能で ある。（親しさに関する先行研究の価值を同定する）

3.「透明性の錯覚」等心理学的見地は参照されるべきものであるが、それらは（その研究 デザイン上）日常性という視点に欠けている、または、実際の応用的・機能的意味につ いては考察が不十分である。

以上の三点は、本研究の動機でもあり、本研究を「行わなければならない」理由でもあ る。また、研究デザインにおいても、同様のことが言えるであろう。

この場合のインセンティブ (incentive) とは、「推測が正しいこと」で報酬を得られるといったような外的動機のことである ○藤（2007）では、このインセンティブにより、透明性の錯覚における社会的規範の影響が小さくなると仮説を立てたが、 棄却された。 


\section{研究の方法}

\section{使用データ}

本研究で使用寸るデータは、付き合って半年になるあるカップルのインターネットチャ ットでの会話を収集したもので、2011年3月から6月にわたって継続的に採集されたA4用紙に して60ページ (10万文字程度) の言語データである。データでの会話参与者は二名で、I国 に在住する 20 代前半の男性（仮名：アンドウタクヤ）と、大阪に居住する 20 代前半の女性（ 仮名 : オオウエカナエ) のカップルである。（ただし、データの最初ではまだ男性が日本に 滞在しているデータも存在する。その際は別途明言する。）なお、アンドウはオオウエより 3歳年上であり、同じ大学の先輩であった。

インターネットを利用したチャットソフトSkype ${ }^{7}$ での文字列をコピー・アンド・ペース トで保存し、そのまま分析資料とした。なお、このインターネットチャットのソフトウェア にはビデオ付きの通話機能が存在するため、ビデオ付き通話を行っている部分は資料から除 かれている。

この言語資料での特徴は、インターネット上での二者間のみによる会話という点で特徵 づけられている。つまり、対面ではない遠隔で行われている（2時間の時差も存在する）こ と、また、二者間のみであり、Goffman(1981)のいう参与者枠組み (Participation Framework）のもつともプリミティブな発話者・被発話者という枠組みが適用されており、 そこに存在する会話のアドレスは、特別なコンテクストがない限りにおいて、それぞれ話中 の相手に向けて発話されていると考えることができるだろう。さらに、視線や、ジェスチャ 一といった非言語的相互行為や、アクセント、イントネーション、声色、顔の表情などを見 ることはできない。また、発話が秒単位でしか計測できないため、発話のタイミング等は推 測に頼らざるを得ず、それゆえ、発話の「仕方」よりも発話の「内容」により重きが置かれ ること（あるいは、置かざるを得ないこと）は、分析を行うに先立って述べておく必要があ るであろう。

\section{分析方法}

本稿の分析は、会話分析（ConversationalAnalysis）の手法を用いている。会話分析は 、エスノメソドロジー（Ethnomethodology）での主流的研究方法である（山田，好井，山崎， 1987:p.7)そして、「エスノメソドロジストたちは、会話そのものに関心を寄せているわけ ではないし、まして言語に特別の関心をもっているわけでもない」（好井, 1992）と述べられ ている。しかし、本研究では会話そのもの、つまり「話し方」と「話されている内容」は分 かちがたく存在していると位置付けている

8。よって本稿では、話されている内容とその機能的位置づけにおいても言及したい。

本稿では、チャットでのデータ（以下、チャットデータ）を時系列に沿って読み、その なかで「おおよそ、親しくない二者間では起こり得ないと思われる出来事」を抽出・分析す る。これは通常、友人たちや参与社会に存在する半知りの人々と話すような一般的な会話（ GeneralConversation）ではなく、「付き合う」という二者間において（のみ？）起こるで あろうと考えられる特異な会話（Peculiar Conversation）であることを示している

\footnotetext{
${ }^{7}$ Skypeの詳細な機能については公式サイト（http://www.skype.com/ 最終アクセス：2012/1/24）を参照。 8 詳しくは千々岩（2011）を参照されたい。
} 
i。それら会話を、前後のコンテクストを含めて抽出し、なにが行われているかを大まかに 現象別に書きだし、分類した。その後、それぞれの現象を大きくまとめ、さらに付き合う二 者間で特徵のあると考えられる現象 3 種類に分析対象を限定した

9。それらはすべて「相手を知っている」ということに基づいているため、それら分析対象 群を「相手を知っていること」と呼ぶ。

なお、フォローアップインタビューを実施し、発話の以前にある二者の共通知識につい て問う必要がある場合について質問を行い、そのことが共通の認識として存在したことを確 認する作業も行っている。

\section{データ分析・結果と考察}

第四節では、第三節で示したデータを詳しく分析していき、会話の中に存在する「相手 を知っている」ということがどのような二者の関係とかかわっているのか、分析を試みる。

これらの「相手を知っている」という要素を含意するデータは、言語資料から抽出され たものであり、これ以上の活動が、今回の言語対象の二者間における対面の場合や、他の力 ップルで行われている可能性については否定できない。しかし、冒頭述べたような状況的な 制約があり、さらに適用できる範囲は限られているものの、二者間のストラテジーを抽出す ることに全く意味がないとはいえないのではないだろうか。というのも、これら彼らが使用 しているストラテジーは、彼らが今までの社会の中で他者とのインタラクションを通して獲

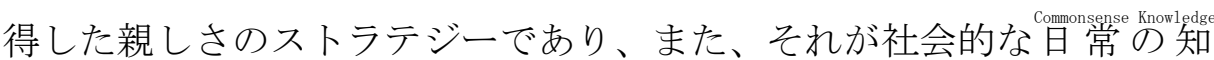

により培われてきたものであるとすれば、他の社会の構成員が類似した、あるいは同じ活動 を行っているはずだということは想像に難くないからである。

本節では、言語資料中に発見された「相手を知っている」と述べることを分析し、それ が二者間でどのような相互行為であるのかを明らかにする。

\section{認識の類似について言及すること}

チャットデータ $1<$ 開かずの観賞室 $>^{\mathrm{ii}}$

新入部員のために、Kキャンパスを案内した方がいいと言う話をしている。タクヤは以 前カナエを案内しているため、カナエは他の部員よりもKキャンパスの地理に明るい。[2011 /04/04]

01 [19:34:25] タクヤ：いや、案内してあげないと、かわいそうだよ

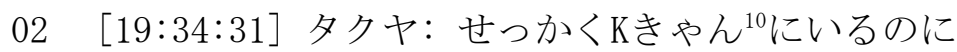

03 [19:34:41] タクヤ：映画部員としてのファーストステップだよ！

04 [19:34:53] タクヤ: (ninja)

05 （（著者注：忍者の絵文字（Emoticon）が表示されている））

06 [19:34:58] カナエ：どこを案内しろと?

07 [19:35:01] タクヤ：部室

08 [19:35:06] タクヤ：と、部室。

$\rightarrow 09$ [19:35:09] タクヤ：と、部室。

9 限定は多くのデータから帰納的に取り出しているため、操作的とは言えない。また、分析対象の限定は紙幅上の都合による。 $10 \mathrm{~K} や ん$ 二人の大学のキャンパスの一つ。「きやん」はキャンパスの意。 


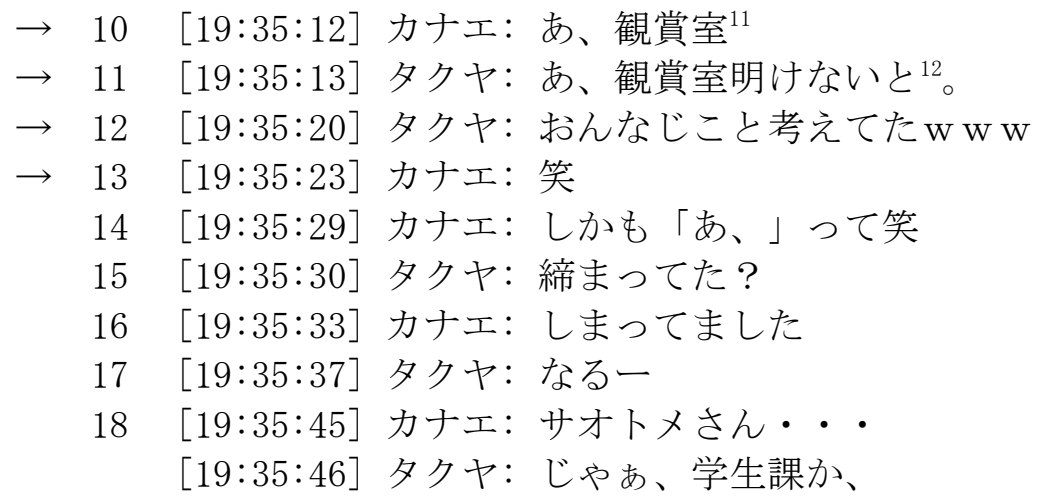

以下、部活の中での役割の分担の話になる。

01で、タクヤ（以下、Tと記載）は新入部員にキャンパスを案内しないことは、かわい そうなことであると述べている。さらに、02でキャンパスに居るのに案内しないことの「も つたいなさ」を語る。そして、03では、それが映画部員となる第一段階であることを示し、

「忍者」の絵文字を使用する（04）。この絵文字の使用意図は不確かであるが、04から05 12秒程度間があることから、Kへのターン交代の表示か、Kへの発話催促ではないかと考えら れる。その証拠に、Kは5秒後に、案内寸る場所はどこが適切かということをTに尋ねる（05 ）。Tは「部室」と06で解答し、さらに選択肢を示す目的ではなく部室しか場所がないこと を示すように「と、部室。」と、07と08で繰り返す。その3秒後、KとTは一秒差というほぼ 同じタイミング

13で、観賞室について述べる。その際、09のKよりも、10のTの方が、観賞室への態度（この 場合では、開けなければらないということ）がより明確に表れている。11では、この09と10

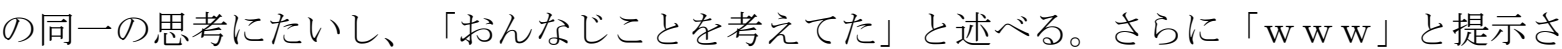
れていることから、それがTにとって異常な事態であることがうかがわれる。12でKはそれに 同調し、13で観賞室もさることながら（=しかも）、「あ、」という感嘆詞までも同じであ ることを指摘する。14でTは、それには触れず、「観賞室が締まっていたか」という事実を 確認し、15でKはそれに答える。16でTは「なる（ほど）」と述心゙、17でKは「サオトメさん ・・・と現部長の名前をタイプする。このサオトメという人物は、部長としての責務を果 たさないという点で、二人の話題に上っていたことがあった。ここで観賞室が開いていない 事態に対し、サオトメの名前を出したことは、その責任について言及することを含んでいる ものであると考えられる。18でTは、サオトメさん発言については触れずに、観賞室を開け るための手立て（この場合では学生課に行くこと）を示唆する。

ここで特異だと考えられる点は、09～13で起こる「同じことを言うこと」である。この 現象が起こることは、06から09で繰り返し述べられている「部室」が、二人の中で「観賞室 が開いていないこと」を想起させるリソースとして働いていることに由来する。そのことは この現象が起こる背景に「部室」から派生する認識が、TとKの二者間で非常に類似してい ることを示している。このように、同じ言葉を述べ、それについて言及することは、キーワ

観賞室が手違いでカギをかけられてしまい、大学の事務所まで行き開けてもらわなければいけないことから、ずっと鍵がかか っている状態であることが、二者の共通知識としてあった。

12 以下の「締まっていた」ということから「開けないと」のミスタイプだと考えられる。 13

一秒では、10のTの発言は打つことができない。パソコンの特性上、最低 26 個のキーを打たねばならぬため、一秒では難しい であろうと考えられる。ゆえに、これはTが $11 て ゙$ 述べるとおり、「同じことを考えていた」ことになる。 
ードへ遡り、そこからの「認識の類似を示す」ことを行っているとみられる。また、「あ、 」が重なったことについても、13でKが言及しているとおり、また、「笑」で示されている 通り、通常とは違う異常な行為であることは明確だが、それにより、二人の認識の類似性を 強調していることとも言える。では、チャットデータ1の「ある言葉が二者間に同じことを 想起させ、そのことに言及する」例として、チャットデータ2を見る。

\section{チャットデータ2 <豆太>}

人は写真を撮るのが趣味である。タクヤは、カナエに写真をネット上でデータで送信し 、意見を求める。

[2011/05/12]

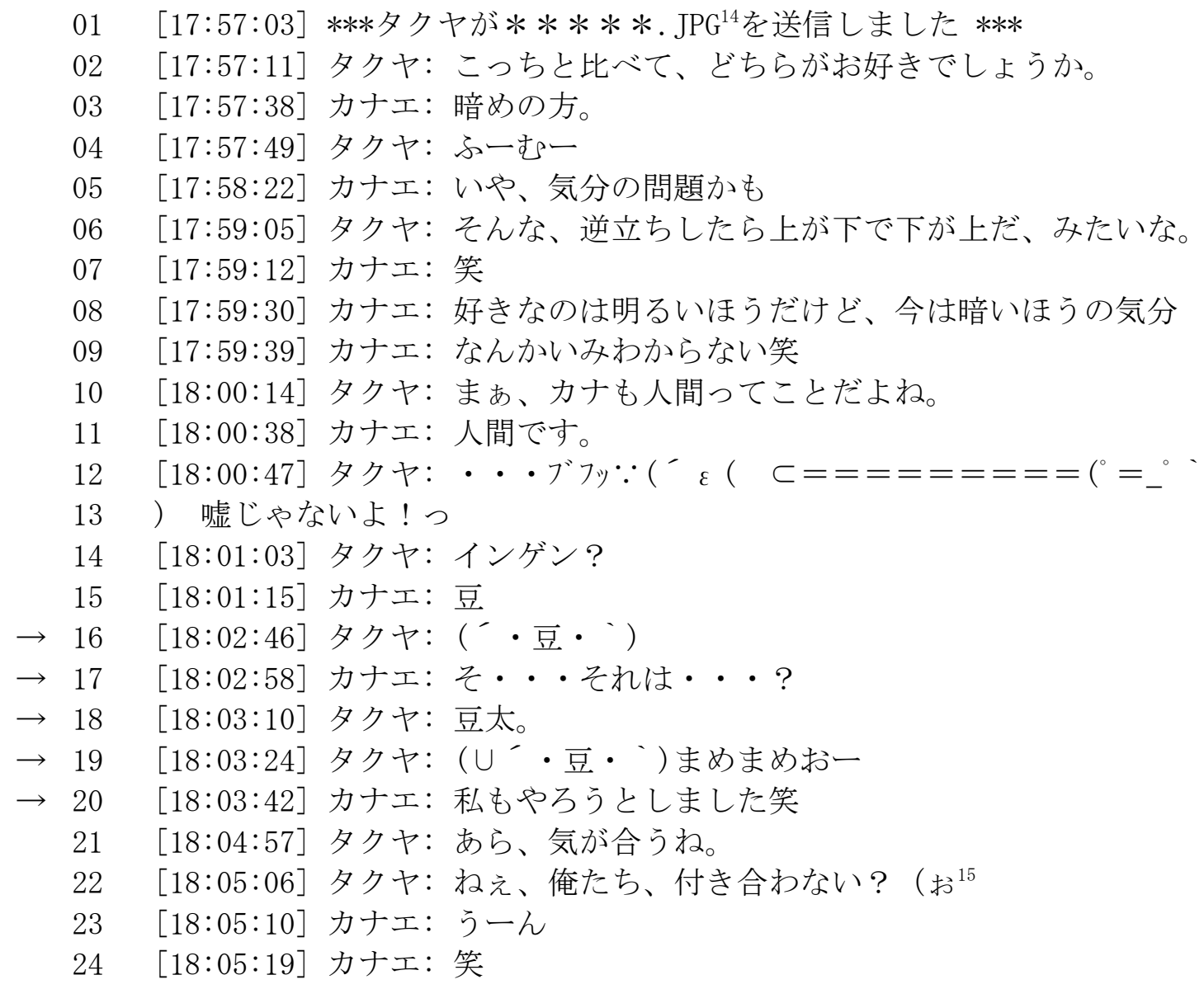

その後、付き合っていない状態を仮定した圥談をタクヤが繰り返す。

会話は01のTが写真のデータを送信するところから始まる。02でTは、Kに対して二つの写真 でじちらが好みかどうかを尋ねる。

\footnotetext{
$14 \mathrm{JPG}$ 画像の拡張子の一つ。*****と合わせ、タクヤがカナエに送信したファイルの名前である。 15 ここでは二人は別れておらず、付き合っている。
} 
この際、注目すべき点は、文末が丁寧体表現になっているということである。この二人 の場合、通常話されているスピーチスタイル（いわゆる「基調」）は、KからTが丁寧体、な らびに語末を省略した表現（08）、および普通体（09）と混合して使用されている ${ }^{16}$ のに対し、TからKへは普通体（大阪方言も使用される）である。これはおそらく、この付 き合うという恋人関係へと移行する前に、同じ専攻・部活の先輩・後輩関係であったという ことが影響していると考えられる。しかし、ここで02の文末がそれに反し、丁寧体である。 これは、おそらく「頼みごとをする 頼みごとを引き受ける」と言う二者間の役割において 、頼みごとをすることが相手に対しての負担をかける行動であるため、ここでは二者間での 関係よりも濃く表れてスピーチスタイルのシフトが起こっていると考えられる。

03でKは、比べた写真では暗めの方が好みであることをTに告げる。Tは「ふーむい」と 、Kの判断がTの意思とは異なっていることを示す。05でKは、それを受け、それが「気分の 問題」であるという。06でTは、その類似例として逆立ちした時の状態を提示し、軽く非難 する。Kは笑とTに対して「ごまかしの笑い」（早川2000）を行い、03の判断が好きなものと 今の気分が背反したものであると述べる（07）。08でKは、さらに05の補足として、気分の 問題でその好みの判断が摇らいでいることを述べ、09で08が補足として不適当であることを 示し、自らでも判断についてよくわからない状態であることを述べる。10で、TはKの一連の 気分の問題による判断の摇れについて、あなたも人間であるのでそれは仕方がないと述べる 。11でKは人間です、とTを肯定し、それに対し12、13でTは嘘じゃないよ、とピノキオ ${ }^{17}$ の顔文字を使う。これにより、暗に「あなたは人間ではない」と圥談風に述べていること も考えられる。14でさらに「人間」と「インゲン」と聞き間違えたように（視覚上のデータ であるため、聞き間違えることはない）発話をデザインし、Kは15で豆と答える。14でのデ ザインは、インターネット会話独特のもので、視覚上で行われるチャットのやり取りでは聞 き間違えることがないにもかかわらず、聞き間違えたようにデザインするということは、ま さに日常の会話でのストラテジーがインターネットチャットにも適用されている例であると 言えるであろう。16でTは顔文字の中に「豆」という字を組み込んだものを提示し、17でKは それが何かを問う。Tは18でその名前（豆太）を述べ、さに14秒後に「豆」と犬の顔文字

$\left(\left(U^{\wedge} \omega^{\wedge}\right)\right.$

わんわんお！）を組み合わせたものを作る。20でカナエは、それに対し「私もやろうとしま した」と、Tに対してその行為が、自分がしようとした行為と同じであることを述べる。Tは 21で二人の気が合うこと、そして、22で（すでに付き合っているけれども付き合っていなデ ザインで）付き合わないか、と問う。その際に「（お」と述べているのは、それがて談であ ると示すためであろう。それに対し、Kは23で「うーん」と圥談に対してのコメントを避け 、それが否定的に取られないために「笑」と付け加える（24）。

ここで注目したい点は、20で行われているKの「私もやろうとしました笑」という発話 である。この発話は、16での「豆」という漢字を用いたTの顔文字の装飾（おそらく顔文字( ・ $\omega$ ・`ショボーン) に対しての連鎖（16での新しい要素の提示、17での16に対する質問、18で の応答）が終了した後に出てくる19のTの顔文字発話に対するコメントである。ここでの論 点は、「なぜ」このような発言を行うことが、Kにとって必要であったのかというものであ る。ここで、チャットデータ $1<$ 開かずの観賞室 >での理論の適用が可能である。「ある言 葉からの認識の派生が類似であること」を示しているのだ。つまり、16での顔文字（(`・

16

このことはより詳しく調査されるべきであろうと考える。というのも、親しさによってスピーチスタイルシフトが起こること は我々にとっては日常知であるが、どの段階でどのように行われるかについては今まで不明確であるからだ。

17 童話ピノキオで主人公のピノキオは嘘をつくと鼻が伸びてしまうことから。 
豆・・)）に対する認識の派生方法が、TとKで似通っていることを明示的に示すために、Kは このような発話を行ったと考えられる。

以上、チャットデータ1および2で行われている相互行為は、「互いの認識の類似性を示 す」ことにより、「お互いがより近い認知状態にあることを示す」ことを目的としているも のとしてとらえることが妥当であろう。このことが、相手に「認識的に寄り添おう」とする 行為なのであれば、それは二者間でどのような機能を持つのであろうか。

村山（2004）は、顧客と従業員を対象に行った親密度の長期的調査の結果で、友人関係 における関係深化の要因として「本音の自己開示」「なんらかの類似性の存在」「相手の立 場にたった心配り」の三つを挙げている。この「なんらかの類似性の存在」というのは、楠 見（1989）に初出したものであるが、おそらくこれは表層的なものを志向しているように思 える。例えば、飼っているペットの名前が一緒であるとか、妹が二人いることとか、そのよ うないわゆる「モノの偶発的類似性」についてであろう。

しかし、この会話資料から二人の間で行われているのは、「認識の類似性を相手に示す こと」であり、これがモノ的類似性に関係していながらも、もっと深層的な「思考の類似性 」とも呼ぶべきものである。双方にモノ的類似点があった場合に、人々の間で会話が盛り上 がる一ということは、往々にしてありうるし、想像に難くない。しかし、「事物に対する認 識の類似性」を認知して会話が盛り上がることは、想像しにくいにもかかわらず、このデー 夕に見られるもの二点は確かに、その類似性を相手に示している。よって、この類似性の提 示を親しさのストラテジーと呼ぶべき物理的証拠はないにせよ、それがその一種であること は肯定できる。

\section{相手の行動／性質が予測の範疇だと述べること}

では、「認識の類似性」を相手に示すことによって、二者間の関係がより近い状態にあ ることを提示するデータを示した。では、相手を「どのように認識しているのか」について 言及寸るデータはあるのであろうか。ここでは、そのことに関連したデータを示したい。

チャットデータ 3 ＜パンケーキ＞

二人はTの働き先について話しており、その後、二人が所属している映画部の部長「サ オトメ」と連絡が取れない話になる。[2011/04/14]

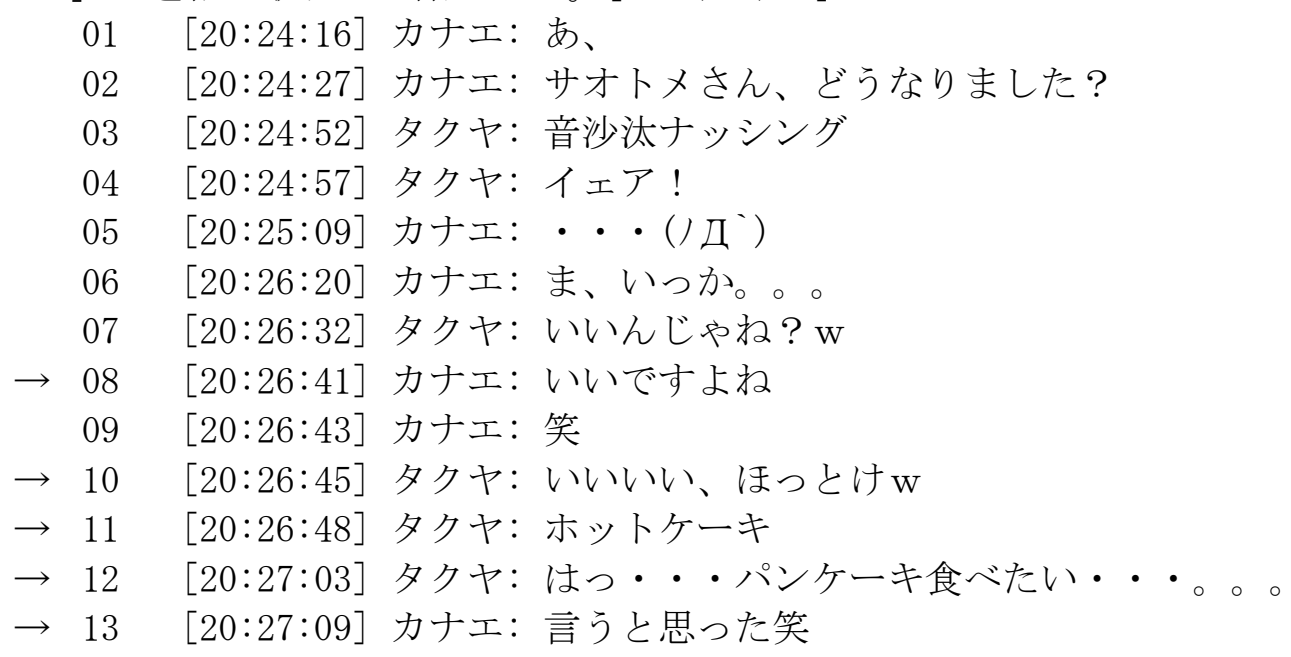




\begin{tabular}{|c|c|c|}
\hline 14 & {$[20: 27: 13]$} & タクヤ： $\mathrm{www}$ \\
\hline 15 & {$[20: 27: 17]$} & タクヤ：おいしいじゃない、パンケーキ。 \\
\hline 16 & {$[20: 27: 25]$} & タクヤ：美味しいパンケーキは美味しいじゃない。 \\
\hline 17 & $: 27: 25]$ & おいしいですよ。 \\
\hline
\end{tabular}

以下、Kはパンケーキを好きであり、それに対し二人の共通の先輩に言及されたという 話になる。

01で、Kは「あ」という言葉で、認識が変化したことが示され、違う話題の提供を行う (この話題の前はTの勤務先についての話）。02で、サオトメという映画部の部長と連絡が 取れたかということをTに尋ねる。Tは、「音沙汰なし」と、英語の「Nothing（何もない） 」を組み合わせた語を03で述べ、それが英語風の表現であることを強調するように「Yeah」 のカタカナ語である言葉を04で述べる。Kはそれに対し、悲しい表情の顔文字を表示する（0 5）。しかし、06では、連絡が取れないことはどちらでもいいことである、という旨の発言 を行う。それに対し、07でTはKに対し賛同する。08でKは、それが妥当である確認を行い、 それを圥談風にデザインしなおす（09）。10でTはKの意見をサポートするために、「いいい い」（この「いい」の繰り返しは、いい、必要ない、ということを強調するためであると考 えられる）と述べ、さらに「放っておけ」と述べる（10）。さらにTは11で「ホットケーキ 」と述べる。これは、「ほおっておけ」から派生した「ほっとけ」を「ホットケ（一キ）」 と読み替えたことによる言語行動で「連想」と呼べるであろう。さらに、12でTは連想を深 め「ホットケーキ」から「パンケーキ」を導き、それを食べたいという欲求の対象であると 述べる。すると、13でKは「言うと思った笑」と、相手の「パンケーキを食べたい発言」が

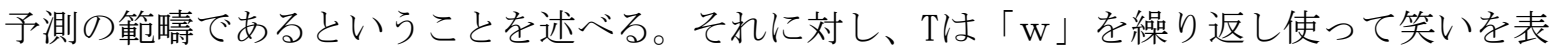
現し（14）、12の発言の妥当性を高め、同意を要求するために「パンケーキがおいしい」こ とを述べる（15）。16ではそれを訂正し、「美味しいパンケーキは美味しい」と、パンケー キの属性をさらに狭め、同意しやすいように程度を下げる。とほぼ同時に（発話された時間 を参照すると、1秒以内の出来事である）Kは「おいしいですよ」とTの15に向けて同意する (16) 。

ここでの注目すべき点は、13におけるKの「言うと思った」という言語活動である。文 末への「笑」の付加により呪談風にデザインされているこの活動は、12のパンケーキを食べ たいという欲求の発露へのコメントである

iii。しかし、その言い方は「言うと思った」という相手の発話を予測するものであり、かつ 、前後のカナエの発言8、17とは違い、スピーチスタイルシフト（Speech Style Shift）

18が行われている。これはいったいどのようなことを指向した活動なのであろうか。

相手の行動を予測していたと述べることは、4.1で述べた「認識の類似性」を提示して いるものとは異なり、相手の行動を予測し「自分の認識へと組み込む」作業である。つまり

「Tがホットケーキから、パンケーキへと連想を深め、それを食べたいということ」は、K にとってはすでに知っていることであり（または知っているとデザインすることが “よい” ことであり、）「私はあなたの行動がわかる。あなたの行動は認識の範疇である」と述べる ことによって、相手に「知られていること」を自覚させ、知られている関係であることを暗 に伝える手法なのである。これが相互的に実現すれば、単に一方的な関係ではなく相互的に

18

この場合では、いわゆる「ため口」と呼ばれるものではなく、Kのいわゆる基調に対し丁寧体が脱落し、再度もとに戻ること を述べている。 
「知り合っている」（ように見える

$\left.{ }^{19}\right)$ 関係になり、互いを互いの認識に組み込む作業につながる。そして、スピーチスタイル シフトが行われていることを加味するのであれば、それは相手への接近を示していることに なるのではないかと思われる。

\section{チャットデータ 4 ＜星の王子様＞}

昔話の話をしている途中で話題が変わり、ある共通の知人について、Tが家業を継げば いいのにと提案する。

[2011/05/28]

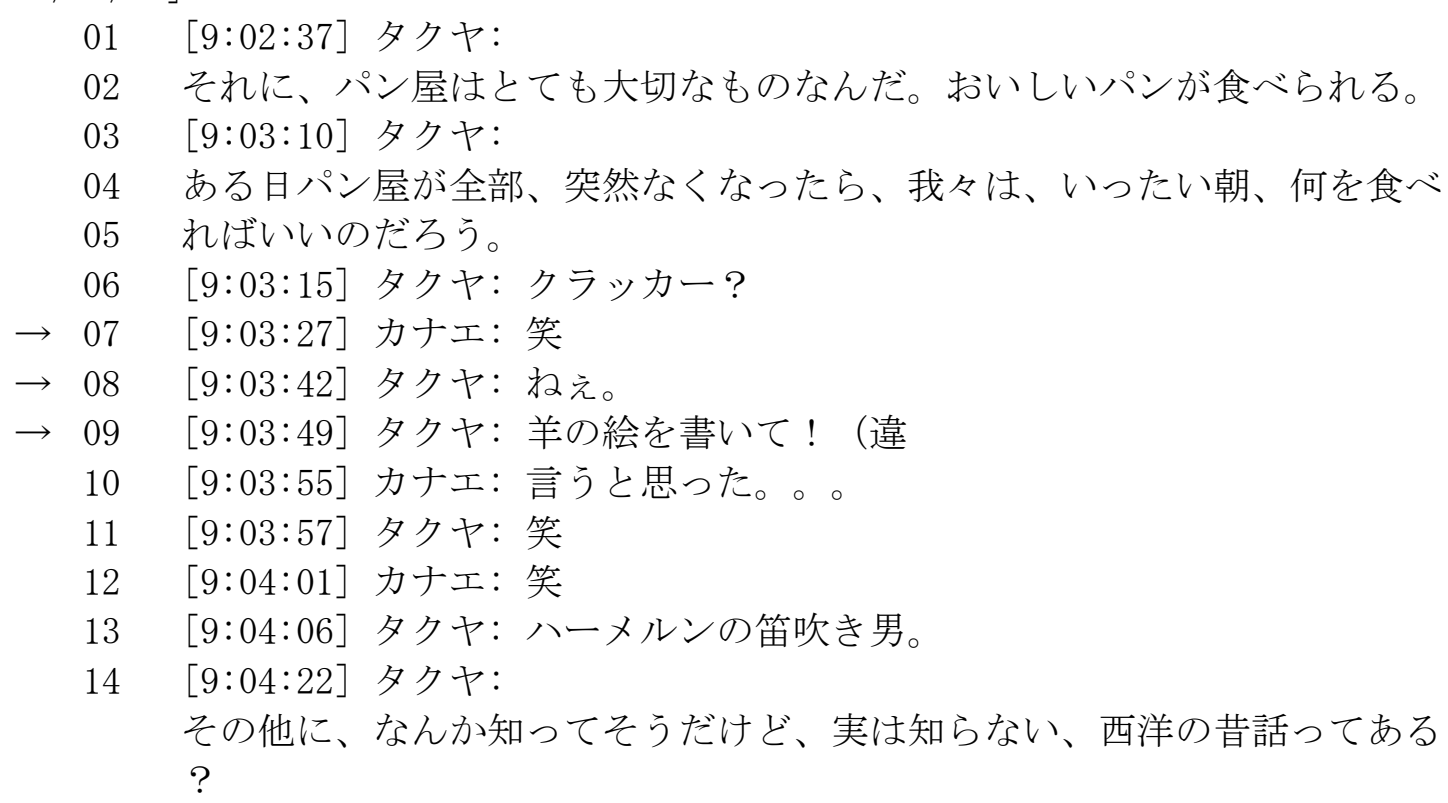

以下、家業の話題の前に話されていた昔話についての話題になる。

ここでは、07と08でチャットデータ3同様の活動が行われている。Tは07で、06までとは 関係のない新しい話題の表示「ねえ」を発話後、08の「羊の絵を書いて」という『星の王子 様』でのフレーズを引用し、それが前の話題と関係のないことを示すために、「違」という 言葉を語尾にカッコつきで付与する。それに対し、09は「言うと思った。。」と、述べる 。ここでは、チャットデータ3と違い、その発言が09の時点では圥談風にデザインされてい ないことである。10でのTの「笑」をうけ、11でKが笑いあうまで、09は攵談化されていない 。そのあと、12でさらに最初の話題である「昔話」の中で登場したハーメルンの笛吹き男の 話題を再度提示する。

この『ねえ、羊の絵を書いて』という表現は、これ以前の会話資料でもたびたび出現す る。よって、この会話では、『ねえ』から派生する言語表現が二者間で常用されていること を示すために、あるいは、09の語末の「。。。」から、何度も使い古された表現に対しての 一種の「呆れ」を表示させるために使用していることが考えられる。どちらの可能性にせよ 、最終的には圥談風にデザインし直されるこの表現は、二者間の認識類似性を双方に提示す る手法であることは考えられる。

19 ここであえてように見えると述べているのは、工藤（2007）で述べられている「透明性の錯覚」の議論による。 
また、この「相手に関する予知が妥当であった」と示す活動は、相手の「行動」に対し ての言及だけではなく、相手の性質についても類似した活動を行うことができる。

\section{チャットデータ 5 <蛇の果物 >}

タクヤが、カナエにサラクと呼ばれるへビの鱗に似た皮を持つ果物を買ってきて、その 画像を送った。その後、その味について話し合っている。[2011/04/16]

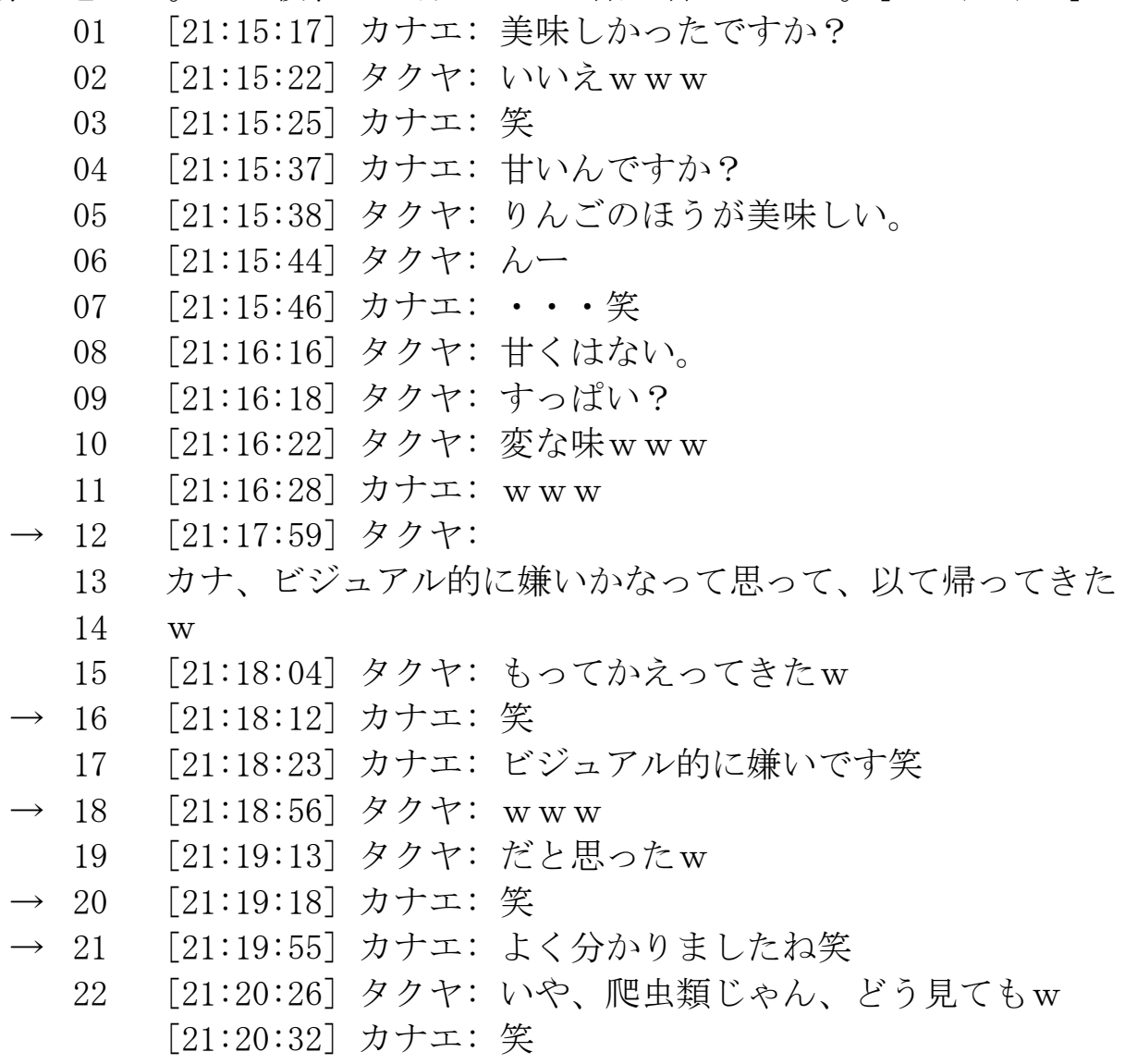

01でKは、その果物の味について、美味しかったかどうか尋ねる。タクヤはそれに対し 、02で「いいえ」と述べる。Kは03でそれに笑いで返し、味の詳細について選択的に（甘い かどうか）尋衩る。05でTは、02への追加情報として「リンゴ」を比較対象として差出し、 そちらのほうが美味しいと述べる。06では、Tは甘いかどうか（04Kの質問）への答えとして

「甘くはない」と否定し、自問する形で「すっぱい?」と疑問形式で提示（09）した後、 変な味、と結論づける（10）。Kはそれに対して同調する笑いを行う（11）。次に、Tは、12 〜13で、このサラクを持って帰ってきたことが「カナ（Kのこと）がビジュアル的に嫌いで あるだろうこと」を志向していたことを述べる。14で、「持って」を「以て」と打ち間違え たことに対しての訂正を行い、15でKは12に対して笑いで返答する。さらに、16で12のTの予 測が正しいことを述べる。それに対し、17でTは笑いで答し、「だと思った」と自ら行っ た予測が正しかったことを再度提示する。Kはそれに対して「笑」と、さらに書き、「よく 分かりましたね笑」と、相手の予測に対して（おそらく肯定的に）コメントする。Tは、そ れに対して、「どう見てもそのサラクは爬虫類のようである」 
20ことを述べ、その推測が自らにおいては妥当であったことを述べ、Kは22で笑いで応答する $\circ$

ここでのT18の発言「だと思ったw」は、チャットデータ3、4の「言うと思った」と同 様の機能を持つと考えられる。Tには、その前から「カナエ」についての先行する二者間共 通の情報（爬虫類の見た目が嫌い）があり、それをいわば駆使して「爬虫類が嫌いであると いうことは、この爬虫類の見た目をした果物も嫌いであるはずだ」という予測を行ったうえ

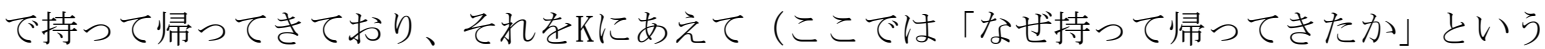
ような問いはKから発せられていない）言うことで、「この行為があなたを知っていたため にできる行為であったのだ」ということを印象付けている（12-

13）。そして、その予測が正しかったとき（16）に、相手の性質が自らの認識のなかで同一 のものであったことを示すために、先述の「だと思った」という言葉が用いられているので ある。

本4.2節では、「相手を自ら認識に組み込む」ことを「相手に示す」ことによる、親し さのストラテジーを見た。チャットデータ 3 と 4 では、「私はあなたの行動がわかる。あなた の行動は認識の範疇である」と述べることによって、相手に「知られていること」を自覚さ せ、知られている関係であることを示すことをしている可能性についてのべた。

また、チャットデータ5では、「相手の性質を認識している」こと、また、「その認識」を 、「相手に示す」場合を考察した。

本節のそれぞれのデータで行われている活動は、相手を「自分の認識の中に組み込む」 作業であり、それが間違いでないことを「相手に示す」ことによって、認識の中に組み込ま れた関係であることが妥当であることを示寸活動である。そして、それが親しさのストラテ ジーとして機能している可能性は、この会話が特異である点、そのことを伝える「理由」に ついての考察、ならびに、周辺のコンテクスト（笑いや、絵文字の使用など）により、十分 にあるであろうと考えられる。

\section{相手の性質を知っていると語ること}

節で示したデータは、どれも連想や予測というある程度前後のコンテクストをもとに、 思考活動によって相手の行動や性質を言い当てるものであった。本4.3節では、その連想や 予測を使用しない、「相手のことを知っている」と端的に述べる活動について考察したい。

\section{チャットデータ6 ＜紙でざっくり>}

カナエが携帯ゲームをしている話から、タクヤが突然21質問をする。 [2011/04/08]

01 [19:31:57] タクヤ：てか、何が痛いの? ?

（（中略 カナエが痛みの原因について話したくない旨の問答がある））

02 [19:33:00] カナエ：いや、ただ手を切っただけです。

03 [19:33:02] カナエ：紙で。

04 [19:33:09] カナエ：結構ざっくり。

\footnotetext{
20 カナエが爬虫類の皮膚の見た目が嫌いであることは、これ以前に述べられている。 21 チャットの前のコンテクストには「痛い」等を示寸言葉はない。おそらく、このチャット外の活動から、このような言及に至 ったと推察される。（そうでなくても、分析に差し支えはないが）
} 


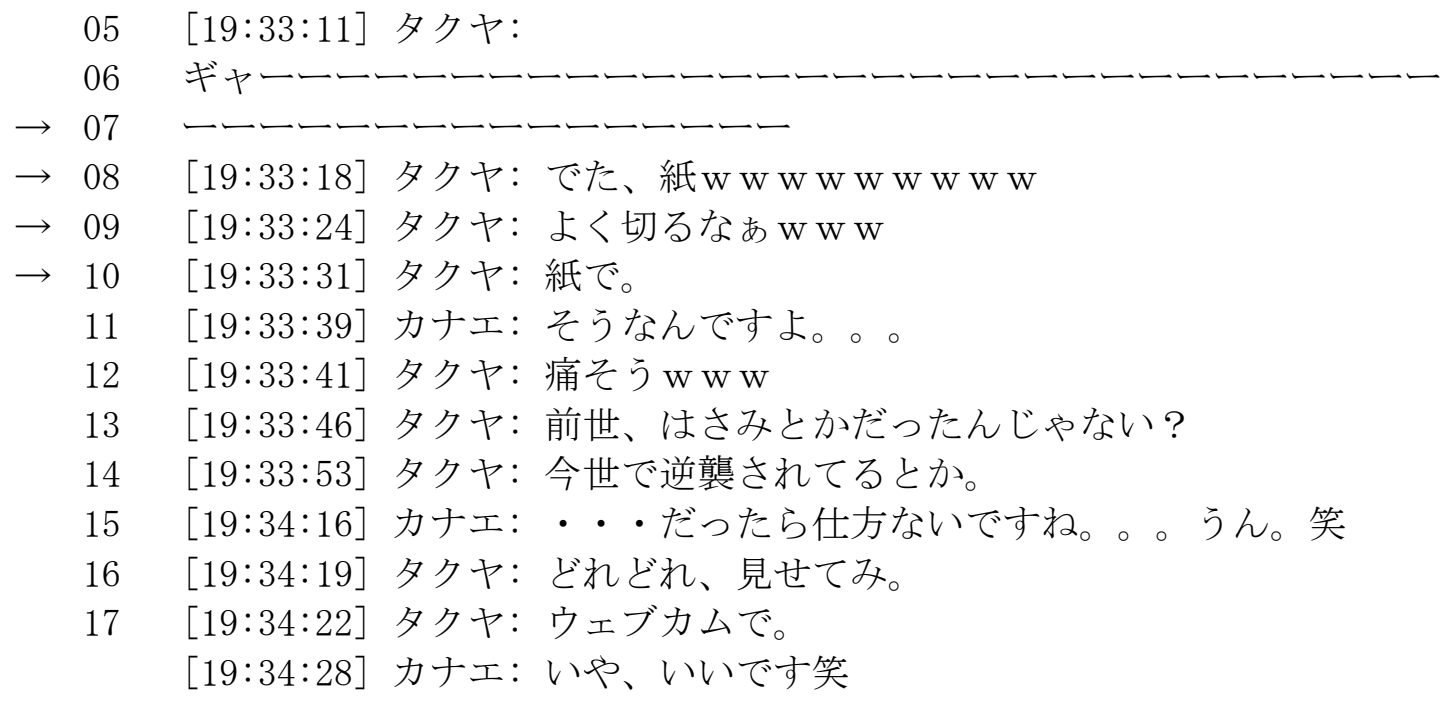

Tの発言07、08、09で行われていることは、どれも相手の傾向（ここでいえば、相手の 「紙でよく切る」という性質）を述べているものである。

ここで注目したいのは、この相手の性質を述べることが、挿入連鎖として存在すること である。02で手を切ったことを述べるKは、03、04でその負傷の原因と、程度をそれぞれ述 べる。その後、05、06でTは叫び声ととれる言葉を書き、そのあと、07で「でた、紙」と圥 談風にデザインして述べる。08、09でさらに、それが「よくあることであること」を述べる 。Kはそれに同意する（10）。Tは、さらに笑いながら「痛そう」と述べる。

この場合、05、06のTの叫び声の次の発話行動として選好（Preferred）なのは、「痛そ う」「大丈夫?」などの、傷に対してのコメントであろう（11で起こっていることである） 。しかし、ここで「相手の性質に述べること（=紙でよく負傷する傾向があるということ） 」が、7-

10 という臨場的場面において挿入されているのは、「大丈夫?」など傷への直接的言及では なく「あなたは前もそのようなことがあった」と言うことで、相手にそれが日常的であるこ とを提示し、それが異常ではないことを提示している。そして、そのような手段に「日常性 」を差し出すことは、二者間がお互いをよく知っていることを暗示しており、その手段をで きることは、二人が「親しい」ことを察知できるその場として機能すると考えられる。

ここで、類似したもう一つのデータを見る。

\section{チャットデータ 7 ＜夜更かし>}

カナエがスカイプのビデオをONにしてくれないことを話していて、分が悪くなったタクヤが 、話をやめようと「おやすみー」と発言する。[2011/04/08]

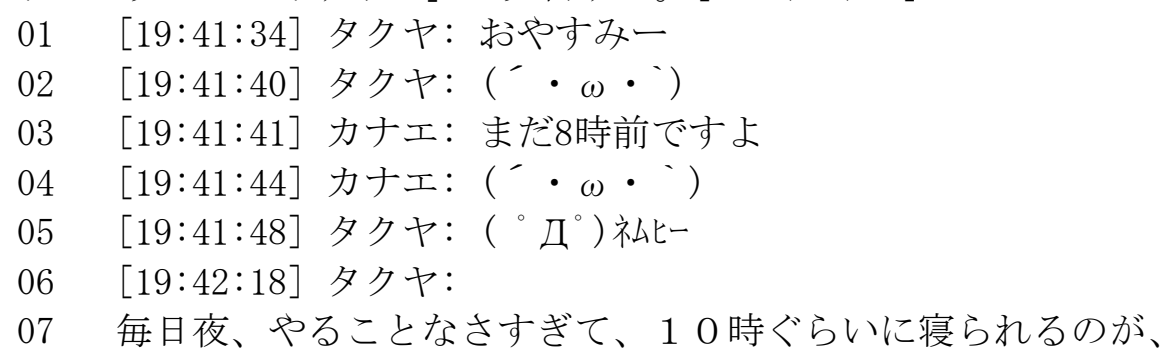




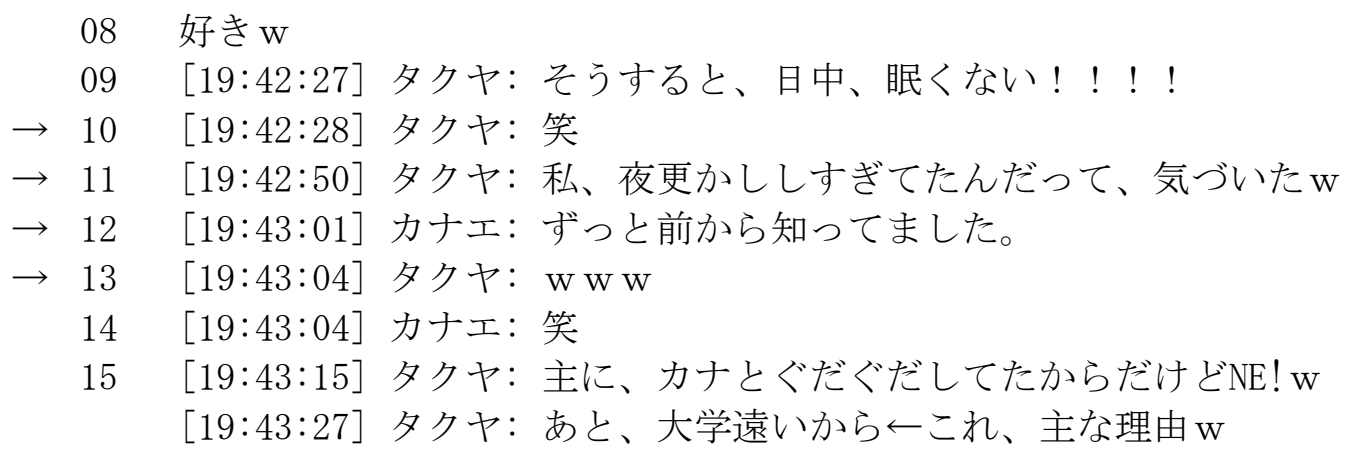

10で、Tは06、07、08と最近の出来事を言及し、「昔夜更かししすぎていたこと」につ いて、気付いた「認識の変化」を述べる。それについて、Kはそのことを「ずっと前から知 っていた」と、そのことについて既知であったことを述べる

${ }^{22}$ 。それに対して、タクヤは笑って返答をする。

ここでのKの11の発言は、Tのこれまでの生活リズムを知っているからこそできるもので あり、「それを述べても問題がない」関係であることが、その発話が行われる裏には隠され ている。そして、Tが「気付いた」ことを、すでに既知のこととして「ずっと前から」と述 べることができることは、その二人に以前からお互いを知り合っていたという文脈的な日常 性を感じさせる。10のKの発言へのTの選好応答を考えると、「そうですか」や、「そうなん ですか」など、相手が述べた認識の変化に対してそれを受け入れるような発言が選好応答だ と考えられるが、そこであえて「私はあなたの性質のことを前から知っていました」という ことをしていることは、相手に対して親しさを提示することとして機能していることは、想 像に難くない。

\section{チャットデータ $8<$ 面倒くさいのが嫌い $>$}

人間関係の話をしていて、Tが突然、殺虫剤の話をしだす。[2011/05/19]

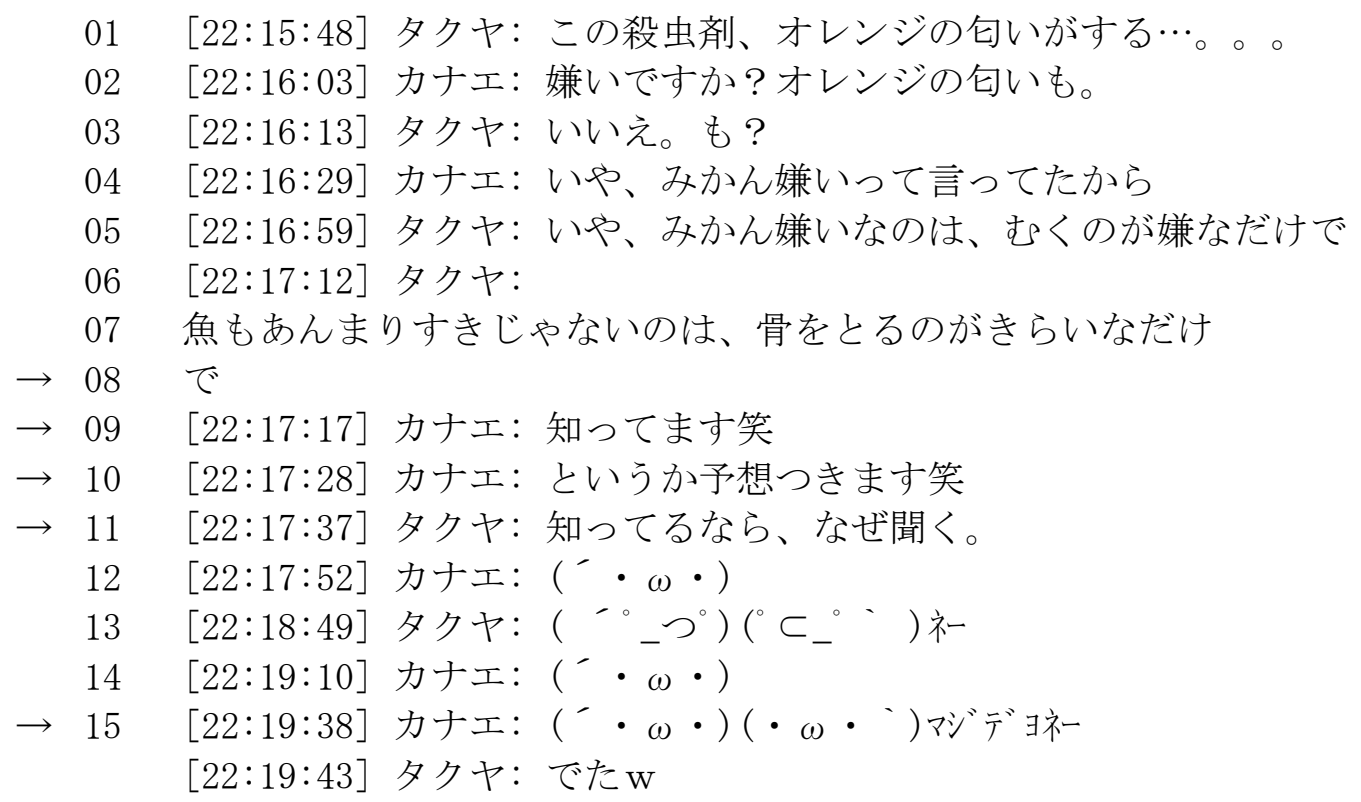

22

ここで、Kが現実として知っていたかどうか、ということはこのデータからはわからない。ここで大切なのは「相手の状態に ついて「既知である」ようにデザインしていること」である。 
以後、そろそろ寝ようかという話になる。

01で、Tは手元にあるとみられる殺虫剤のにおいの話に触れる。それに対し02でKは、才 レンジの匂い「も」嫌いであるか、と尋衫る。03でTは、嫌いですか、という質問に答える ベく「いいえ。」と答え、さらに「も?」と取り立て助詞に触れる。Kは「も」の真意につ いて「みかんが嫌いと言っていたこと」を理由として提示寸る。ここで述べられていること は、「ミカンが嫌い、と言われていたことから、オレンジの匂い「も」嫌いなのか」という KからTへの疑問を再構成し直すものである。それに対し、Tは05で、ミカン嫌いな理由を、 皮をむくのが嫌いであると述べることによって、オレンジの匂いが嫌いであることを否定し ている。さらに、その「面倒くささ」を強化するために、魚についても述べている（0607）。Kはそれに対し、「知ってます」とそれが異常であること笑いで示した後、「知って いるのではなく、予想がつく」とより現象を詳細に説明するために、言い換えを行っている

この相手の性質を知っているという行為（08）、または、それが予想の範囲内であると述 ベる行為（09）は、チャットデータ4、7でそれぞれのTの行動が認識の範囲内であるとした Kの活動と類似している。つまりここでも、「相手に自分の性質が知られていること」を自 覚させ、知られている関係であることを暗に伝える手法として登場している。

しかしながら、ここでTは、その「予想」に対して、知っているならなぜ「オレンジの 匂いも嫌い」と聞いたのか、その質問の意図について疑問を述べる形で発言する（10）。こ れは、単に発話意図を聞いているわけではなく、「本当に聞く前に知っていたのか」という ある種の相手の行動に批判的な対処をしていると見受けられる。その証拠に、それに対し、

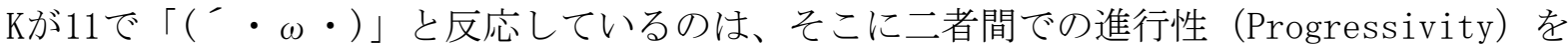
阻害する衝突（Conflict）があったことを示唆する。

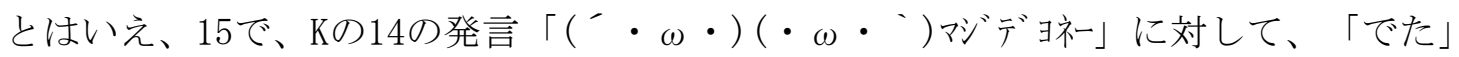
に加え「W」が呪談としてデザインされていることから、この衝突は大きなものとならずこ こで収束しているように判断されている。

しかし、このチャットデータ8から見られるのは、この親しさのストラテジーには、大 きなリスクが伴っているということである。それは、相手を認識に組み込むことが、相手の 心情にコンフリクトとしてマイナスに作用してしまうことがあるのではないかという危険性 である。そのことを、このチャットデータ8は内包している。

4. 3節では、選好応答、周辺のコンテクスト、日常性などの観点から、「相手の性質を 知っていると述べること」について考察した。多くの場合、それらの発話は、選好応答とは 別の形で提示され、なおかつ、二人の過去での共通の理解や、相手の過去の出来事などに言 及していた。そして、これは多くの場合で二人の共通の知識や共通の認識を相手に差し出す 方法として機能しており、その行為の動機となっているのは、親しさの面の強調であろうと 考えるのは、決して不自然なことではない。

しかし、チャットデータ8でも見たように、そのストラテジーは、他者を「知っている 」という心理学的側面における見地である「透明性の錯覚」とも強い関連性を見せ、それが 錯覚であった場合、また、それが偽りであると判断された場合、進行性が阻害され、衝突が 起こることも、一つの現象として確認された。 


\section{全体考察とまとめ}

本研究では、第4節を通し、付き合う男女二者間で起こった言語活動による二者間の関 係の「親しさのストラテジー」を帰納的に抽出しようと試みた。今回のデータで観察された 言語活動を類型化してみると、以下のようになる。

A : 認識の類似性を相手に示す

$B$ : 発話に対して認識的に寄り添うことを示す

（「私もそれを言おうと思っていました」の類）

C : 自分の認識へ相手を組み込むことを示す（「言うと思った」の類）

D : 相手の性質・傾向を理解していることを示す

$$
\text { （「だと思った・よくVするなあ」の類） }
$$

そして、これらに共通するのは、「相手を知っている」ことを示す、ということである。A 類であれば思考が同じであるということ、B類であれば相手の認識を、C類であれば相手を認 識へ組み込み、D類であれば相手の性質・傾向を、それぞれ「知っている」と指向する相手 へ向けて伝達しようとするのである。あるいは、人が言語で思考するという観点で見れば、 その状態を回帰的に自分に植え付けようとしているのかもしれない。いずれにせよ、相手を 知っていること、相手に知られていることを確認することが、二者間の「親しさのストラテ ジー」として使用されている。

心理学的見地での「透明性の錯覚」についての研究は、主に相手に自分の思考がばれて いると認知寸る傾向の言説であった。しかし、ここで行われていることは、発話者が被発話 者に対して「知っている」と述べる行為であり、被発話者は「知られている」と示される、 という活動であった。とすれば、被発話者は発話者からの言葉によって、「透明性の錯覚」 を強められている、ととることができるだろう。そして、「透明性を強く錯覚すること／強 く錯覚させること」が、親しさのストラテジーの根幹的な原理である可能性は否定できない 。また、工藤（2007）が述べたように、相手の考えがわかると錯覚する傾向において語られ たその錯覚をより的確にする「インセンティブ」についても、「親しくなりたい」という動 機が、そのインセンティブとして日常の文脈の中で働いている、と仮定すれば、この説明は より真実味を増す。ここで行われた親しさのストラテジーを仮定を含めまとめると、次のよ うになるだろう。

「付き合う男女二者間による、チャット会話における親しさのストラテジーの一端には、相 手を「知っている」ことを示すことで、相手の透明性の錯覚を強めることがある。また、そ の動機は、相手とより親しくなりたいというものである。」

本研究デザインでは、操作的定義や演繹的な研究を避け、帰納的研究に重点を置いた。 また、少数のデータからの質的研究という点から、これがこの二者間以外に適応可能かとい う議論は、いまだに残っている。だが、4節の冒頭で述べたように、このストラテジーは、 彼らが今までの社会の中で他者とのインタラクションを通して獲得した親しさのストラテジ 一であるため、他の社会の構成員が類似した、あるいは同じ活動を行っているはずであるこ とは、特記しておく必要がある。

今後の課題として考えられるのは、より量的に充実したものにすること、また、仮定段階 での言説を別の方法を用いて研究すること、また、このストラテジーが「どのくらいの」親 しさで使われるのかという観点からの研究の必要性があるだろう。 


\section{文献目録}

$<$ 英文 $>$

Goffman, E. (1981). Forms of Talk. University of Pennsylvania Press.

$<$ 和文 $>$

加藤篤志 （2008）「対人関係の言説分析に向けて」『人文コミュニケーション学科論集』5, pp. 13-20, 茨城大学人文学部紀要.

楠見幸子 (1989) 「友人関係の各位相に関わる要因について」日本グループ・ダイナミックス 学会，第36回大会研究発表論文集. pp. 21-22.

久保真人 (1993)「行動特性からみた関係の親密さ－RCIの妥当性と限界一」『実験社会心理 学研究』第33巻 第 1 号, pp. 01-10.

クレスウェルJ.W. , プラノ クラークV.L. (2010)『人間科学のための混合研究法』（大谷順子 訳）北大路書房

工藤恵理子 (2007) 「親密な関係におけるメタ認知バイアス

一友人間の透明性の錯覚における社会的規範仮説の検討一」実験社会心理学研究， Vol. 46, No. 1, 63-77. (2007).

鈴木孝夫 (1973)『ことばと文化』。岩波書店

大坊郁夫 (2004)「親密な関係を映す対人コミュニケーション」『対人社会心理学研究』 pp. 1-10, 大阪大学大学院人間科学研究科対人社会心理学研究室.

高木智世. （2009）「社会的実践としての日常会話 II -「親しさ」の実践一」『論叢現代語現代文化2009』Vo1.03, pp. 47-64.

田中ゆかり（1999）「大学生の呼称

場面・上下・性の異なる相手からの呼ばれ方」青山学院女子短期大学総合文化研究 所年報 7 .

千々岩宏晃 (2011)「「付き合う」ことによる会話の変化」大阪大学外国語学部国際文化学科 卒業論文.

中山晶子 (2003)「親しさのコミュニケーション」くろしお出版.

早川治子 (2000a)「相互行為としての「笑い」」『文学部紀要』第14-1号pp. 01-24, 文教大学文学部

早川治子 (2000b)「「笑い」の分類に基づく数量的分析」『文学部紀要』第14-2号pp. 01-24, 文教大学文学部

前澤温子 (2008)「親しさを築く日本人学生と留学生の調整行動」千葉大学大学院人文社会科 学研究科研究プロジェクト報告書第198集『言語生成と言語管理の学際的研究』接触場面の言語管理研究Vol. 6 村岡英裕編 千葉大学大学院人文社会科学研究科. 
村山和恵 (2007) 「顧客と従業員との親密な長期的関係に関する一考察」新潟青陵大学紀要, 第 7 号, pp. 223-236.

ライターK(1987)『エスノメソドロジーとは何か』（高山眞知子，訳）新曜社.

山田富秋,

好井裕明, 山崎敬一。

(1987).『エスノメソドロジー 社会学的思考の解体』せりか書房.

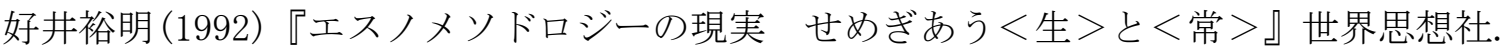

※なお、言語資料内に使用されている顔文字の主な解説は、以下のURLに依った

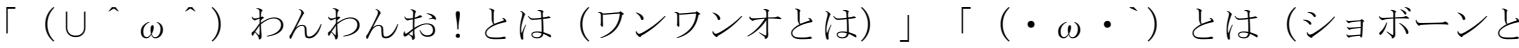
は)」

http://dic.nicovideo. jp/（最終アクセス：2012年2月2日）

\section{文末脚注}

iエスノメソドロジーの目的は「日常知（common sense knowledge）」の解明（ライター，

1987）であると述べられている。それゆえ、ここで分析に使用寸る特異な会話がある程度間主観的に抽出されていることにつ いては問題ではない。というのも、「特異な会話であると判断すること」はおそらく誰においてもそうであろうという日常知 そのものであり、それは分析される以前の言語資料的段階であり、なによりも「なぜその部分が選ばれたのか」ということこ そが分析されるべきことであるからである。（もちろん、不特定多数が「特異だと感じた部分」を研究するほうがよいことは 言うまでもないが)

ii チャットデータの見方は以下の通り

チャットデータ 1 チ開かずの観賞室>ii

新入部員のために、Kキャンパスを案内した方がいと言う話をしている。タクヤは以前カナエを案内して いるため、カナエは他の部員よりもKキャンパスの地理に明るい。(4)[2011/04/04]

(5) [19:34:25] タクヤ: いや、案内してあげないと、かわいそうだよ

02 [19:34:31] タクヤ: せっかくKきやんフにいるのに

Q 09 [19:35:12] カナエ: あ、観賞室 ${ }^{8}$

$\rightarrow 10 \quad[19: 35: 13]$ タクヤ: あ、観賞室明けないと9。

(1)チャットデータの番号（2)コンテクストによる大まかな題名（3)前コンテクストの説明（4)発話があった日付[yyyy.mm.dd] (5)データ内の連番号 （6)発話があった時間（日本より2時間遅い）[時 : 分：秒] (7)後述で特記するデータ

iii

13のKの発言が、11のTの「ホットケーキ」という発言を指向しているのではないかという考え方もあるだろう。しかし、発言 の秒数をみると、11から 12 が 15 秒間離れているのに対し、12から 13 が6秒間という比較的短い間に行われていることから、13 の発言が 11 のコメントであると仮定した場合、21秒の間があることになる。このコンテクスト周辺のコメント間の秒数が最 長でも 12 秒の間しかないことを考えると、その間は「不自然な間」になるため、13のKの言語活動は10-

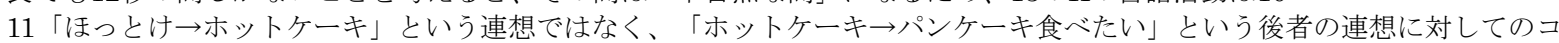
メントであると考えられる。 